\title{
THE EFFECT OF NATURAL HARMONY, SELF-RENEWAL, COMMUNITY, AND HEDONISM ON THE SATISFACTION OF RAFTING ADVENTURE TOURISM PRODUCT CONSUMERS
}

\author{
Zunan Setiawan ${ }^{1}$, Purwoko ${ }^{2}$, Muhammad Ali Fikri ${ }^{3}$, Beni Agus Sulistyo ${ }^{4}$ \\ Postgraduate Program in Master of Management, Faculty of Business Economics \\ University of Ahmad Dahlan Jogjakarta \\ E-mail: zoonan46@gmail.com
}

\begin{abstract}
This research examines the relationship of factors influencing consumer satisfaction namely natural harmony, self-renewal, community, and hedonism towards adventure tourism products. The research used multiple regression analysis to test the factors that influence consumer satisfaction on adventure tourism products. The respondents were 412 people who had taken adventure tours in groups in Yogyakarta and West Java last year. The characteristics of the participants were dominated by men with the age range of 18-50 years, and the occupational background were students and employees. The result of this research revealed that natural harmony, self-renewal, community, and hedonism were positive factors that had a significant influence on customer satisfaction toward rafting adventure tourism products. The research suggestions and implications are also discussed in this research.
\end{abstract}

Keywords: community, customer satisfaction, hedonism, natural harmony, selfrenewal

\section{INTRODUCTION}

The conceptual model of this research is an extension model of (Arnould and Price, 1993) research that employs an experimental perspective. The experiential perspective claims that consumption is seen as a pleasant, encouraging activity and does not emphasize on rationality (Hirschman and Holbrook, 1982). Recently, the most dominant group of tourism products is rafting adventure tourism, especially the rafting adventure tourism which is based on the objects and attractions of natural tourism.
Rafting adventure tourism is a tourism that has physical attributes emphasizing on the elements of challenge, tension, recreation, and obsession achievement or desire of individuals through the involvement with natural elements. Rafting adventure tourism requires the individuals to be physically involved in natural conditions and challenges. In addition, rafting adventure has risks and challenges that must be faced as an adventure tourism (Arnould and Price, 1993).

Furthermore, in its practice, the rafting adventure tourism develops 
commercially on rivers where the difficulty level is safe for children and adults. In general, the service providers, who also act as organizers, elaborate the rafting adventure tourism packages based on the river segments, duration of activities, and certain requirements related to age, ability level, interest, and time availability. Tourists who have adequate experience and expertise in rafting are able to choose several rivers with higher levels of difficulty.

This research focuses on research subjects, namely individuals who have taken the rafting adventure with high involvement and are willing to face challenges and risks. Meanwhile, the research object is the rafting adventure tourism product. This research reveals that there is a gap for the expansion of Arnould and Price's (1993) research model in conducting rafting adventure tourism. Consumer satisfaction in joining the rafting adventure tourism on the river has an opposite perception, meaning that on one side, they experience anxiety, worry, and fear when the rafting adventure tourism process takes place. On the other hand, they also get the pleasure, satisfaction, and memorable experience when they manage to overcome the challenges and rapids and successfully reach the finish line (Arnould and Price 1993).

The best relationship between individuals and nature in the context of the environment is to have natural harmony. Natural harmony is the conformity and closeness to nature, that is, it can create self-development balance including concern for nature and minimize the damage to nature (Arnould and Price, 1993). Based on this description, the first problem of this research is to find out the influence of natural harmony factor on the satisfaction of rafting adventure tourism consumers.

Community is togetherness relationship among individuals in groups forming a unit. Accordingly, it is possible for them to collaborate based on the ownership of information, trust, mutual understanding, equality of values, and mutual support. The experience of doing adventure tourism can lead to personality traits that support the emergence of a community of adventurers. The flow is a key aspect of the community which binds the togetherness among individuals (Csikszentmihalyi and LeFevre, 1989; Arnould and Price, 1993). Therefore, in accordance with this description, the formulation of the second problem in this research is to figure out the community influence on the satisfaction of rafting consumers.

Self-renewal can be perceived by the rafting adventure tourism consumers when they feel the challenge to overcome the rapid and heavy water currents. Self-renewal is obtained through the process of selfawareness including self-confidence, communication skills, responsibilities, and cooperative relationships. Based on this illustration, the third problem to be discussed in this research is to discover the effect of self-renewal on the satisfaction of rafting consumers.

The consumers doing adventure tourism have a tendency to choose fun adventures that they have never done previously. The choices that individuals make as consumers 
are generally based on consideration of whether the product is subjective and symbolic (Holbrook, Chestnut, Terrence, and Greenleaf, 1984; Havlena and Holbrook, 1986).

Hedonism influences consumer satisfaction through difference of choices and considerations of adventure product alternatives based on the number of the product choices available. Hedonism is described as consumer behaviour related to multisensory, fantasy, and emotional aspects (Holbrook and Hirschman, 1982). Based on the description, the fourth problem of this research is to find out the hedonic effect on the satisfaction of rafting consumers.

\section{LITERATURE REVIEW}

The theory of consumer satisfaction (Oliver, 1980; Oliver and DeSarbo, 1988) explains that the factors determining satisfaction are pre-purchase expectations, namely beliefs about anticipated performance of a product, and disconfirmation, that is the difference between pre-purchase expectations and post-purchase perceptions. Adventure tourism products are highinvolvement products since they require more levels of interest from consumers. Stimulus properties in the form of product attributes or verbal stimuli are no longer a benchmark for consumers to choose the product.

Products using non-verbal characteristics, namely something that must be seen, heard, and felt, become a choice for consumers. Moreover, experience consumption gives four important aspects in the model, that are environment, consumers, responses, consequences, criteria, and learning. The aim of expressing an experience perspective is to show the existence of another theory of consumer behaviour and explain the understanding of consumer behaviour more broadly (Otto and Ritchie, 1996).

The direct experience of individuals on nature provides consumer satisfaction through the admiration for the natural environment, especially the swift currents, rocky rapids, coolness, and natural scenery that can provide a feeling of satisfaction (Arnould and Price, 1993). Accordingly, hypothesis 1 is the natural harmony has a positive influence on the satisfaction of rafting adventure tourism consumers.

Communities are formed by the unity among individuals who perform the adventure tours, overcome challenges, and achieve the success together. The adventure tourism consumers need activities that have challenges and risks to avoid daily routine boredom (Arnould and Price, 1993). Consequently, hypothesis 2 states that the community has a positive influence on the satisfaction of rafting adventure tourism consumers. Individual self-renewal is obtained from the awareness of human relations and the natural environment through the love or desire to preserve nature. Selfrenewal of individuals can be carried out through learning new special terms that must be known and become local cultural terminology among consumers of rafting adventure tourism. These terms can be exemplified in demonstrating the use of safety and security equipment, 
teaching rowing techniques, cooking by using bonfires, and various other activities (Arnould and Price, 1993). As a result, hypothesis 3 claims that a self-renewal has a positive influence on the satisfaction of rafting adventure tourism consumers. Individuals will seek satisfaction in certain situations by gaining pleasure, entertainment, fantasy, and happiness. Hedonism can influence the choice of adventure tourism products and has the pleasure effect related to emotion to obtain satisfaction (Holbrook and Hirchman, 1982; William and Holbrook, 1986). Hedonism is associated with sensations generated by experience, symbolic product search, adventure sensations, and acquisition of satisfaction that has never been obtained (Price, Arnould, and Deibler 1995). Therefore, hypothesis 4 states that hedonism has a positive influence on the satisfaction of rafting adventure tourism consumers.

This research examines the effect of natural harmony, community, self-renewal, and hedonism on the satisfaction of rafting adventure tourism consumers. This research uses research objects, namely rafting adventure tourism products. The research subjects are consumers with the characteristics of possessing high involvement personalities. This research paradigm is based on the paradigm of positivism, meaning that the phenomenon that occurs in the research is a measurable objective reality so that the causality can be tested. Positivism logic states that objective reality is the result of social construction describing the permanent and updated phenomenon. The previous research states that the understanding of experience can be based on perspectives namely experience in the natural environment (Arnould and Price, 1993; Celsi, Rose, and Leigh, 1993).

Moreover, the individuals as consumers of adventure tourism products perform active information searches, try to get interesting, challenging, and fun experience, and avoid the boredom of daily routines. Consumer satisfaction occurs through stages in the adventure process so that the satisfaction cannot be perceived if there is no challenge obtained during the stage of the adventure process (Celsi et al 1993). Accordingly, the challenge for the adventure tourism providers is to manage various elements of risk to avoid crises, while at the same time ensuring customer satisfaction (Bitner, Booms, and Tetreault 1990). In rafting adventure tourism, the flow is not only as an absorption of experience that requires active participation, but it also offers pleasure, enjoyment, and satisfaction (Csikszentmihalyi and Judith, 1989). The conceptual model of this research can be explained in Figure 1 below: 


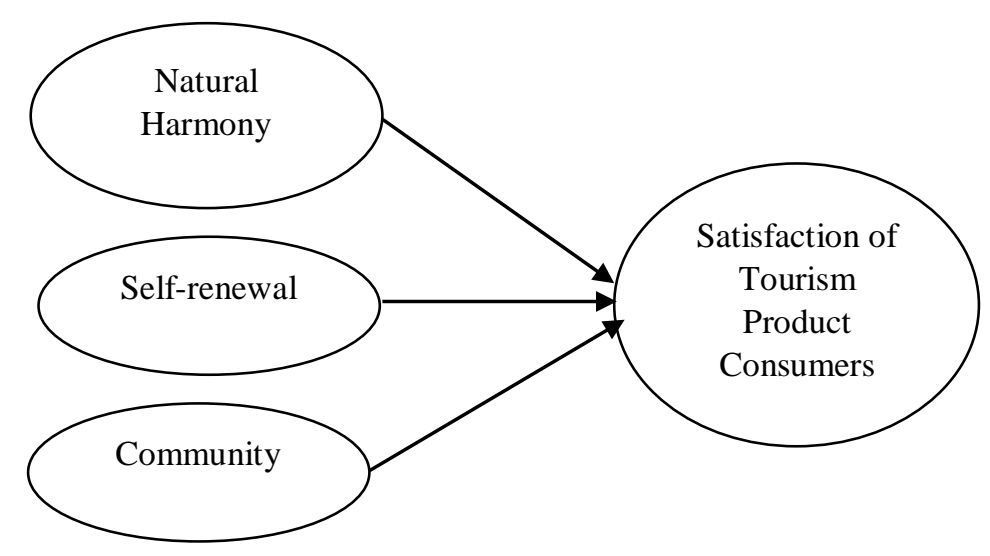

Figure 1. Research Conceptual Model

Source: Arnold and Price, 1993, Holbrook and Hirchman, 1982

\section{METHOD}

This research used a deductive approach, meaning that the research focused more on the development of hypotheses based on the theory. In this research, the data collection employed survey method by filling out questionnaire. The research data sourced from primary and secondary data. The primary data was obtained through surveys by distributing the questionnaires to rafting adventure consumers consisting of two stages, namely pre-test and core questionnaire.

In addition to the primary data, the researcher also used secondary data, namely the data collected through literature studies from various literatures related to consumer satisfaction toward rafting products and the data in the form of published data such as records and reports from companies that provide rafting adventure tourism services.

Data collected in the Citarik and Elo River were 412 respondents. The research data began to be collected since February 13, 2018 to May 20, 2018. The number of questionnaires distributed was 450 copies and the return response rate was 450 copies. The selected consumer population was consumers who used rafting adventure tourism products on the Citarik River in Sukabumi, West Java and Elo River in Magelang, Central Java in the past year. The characteristics of participants were dominated by men with the range of age 18 to 50 years and occupational background, namely students and employees.

Furthermore, the method used to select the research sample was the purposive sampling method, which was one of non-probability sampling method types, namely choosing consumers easily by using certain criteria. This sampling was a nonprobability sample that met certain criteria. The research product was intended for rafting adventure tourism products because of the existence of challenges and risks.

Natural harmony is the suitability, harmony of individuals with the nature through the feelings of closeness and admiration for nature (Arnould and Price 1993). Community is the unity of individuals in groups performing 
adventure tourism activities through the same idealism and selfactualization to overcome challenges and achieve success in rafting. (Arnould and Price, 1993). Furthermore, Self-renewal is the development of individual's ability to overcome challenges (Arnould and Price 1993).

Hedonism is an activity performed by individuals with an emphasis on pleasure and joy aspect (Hirschman and Holbrook 1982). Moreover, consumer satisfaction is the extent to which individuals are happy with the product or service through the interaction of support, purchase, or overall consumer experience. The choice of answers is measured by 5 rate Likert Scale. The testing of questionnaire validity in this research was carried out with the SPSS program.

In Table 1, the result of data feasibility testing showed KMO value of 0.778 . This indicated that overall the correlation among variables was significantly meaningful. In addition, the Bartletts test of Sphericity value of 1035.169 indicated that the number of participants in this research met the adequacy criteria for factor analysis calculation.

Table 1. Data Feasibility Testing

\begin{tabular}{ccc}
\hline Kaiser-Meyer-Olkin & & 0.778 \\
Measure of Sampling Adequacy & Approx. & \\
Bartlett's Test of & Chi-Square & \\
Sphericity & Df & 1035.169 \\
& Sig & 15.000 \\
\hline
\end{tabular}

The result of Bartlett's Test of Sphericity was significance of 0.000 , hence, since the significance was far below 0.05 , the analysis could be proceed. The KMO value, which was close to 1 , meant that these variables could be predicted without errors from other variables. Accordingly, the test results provided assurance that the research data has met the eligibility criteria to be tested by using factor analysis. In addition, this also showed that there was a correlation among variables and the data was feasible for further processing. Furthermore, variables that could be further processed and variables excluded could be seen in the Measures of Sampling Adequacy (MSA) value table below

Table 2. Measuring of Sampling Adequancy (MSA) Value

\begin{tabular}{lccccc}
\hline & $\mathrm{NH}$ & $\mathrm{C}$ & $\mathrm{SR}$ & $\mathrm{H}$ & $\mathrm{CS}$ \\
\hline $\mathrm{NH}$ & 0.803 & & & & \\
$\mathrm{C}$ & & 0.728 & & & \\
$\mathrm{SR}$ & & & 0.788 & & \\
$\mathrm{H}$ & & & & 0.895 & \\
$\mathrm{CS}$ & & & & & 0.801 \\
\hline
\end{tabular}


The table 2 above indicated the MSA magnitude of a variable. The variable of natural harmony was 0.803 , community was 0.728 , selfdevelopment was 0.788 , hedonism was 0.895 , and consumer satisfaction was 0.801 . The MSA value of each variable was > 0.5 ; therefore, all variables could be further processed.

The total variant testing aimed to find out how many factors were formed later. Moreover, the indicator of the items included in the factor was the value of factor loading which had the highest correlation with that factor.

The minimum value of factor loading so that the item could be valid was 0.4 . The results of rotational component matrix were the indications of natural harmony (NH1 - NH4), community (C5 - C7), selfrenewal (SR8 - SR12), hedonism (H18 - H20), consumer satisfaction (CS21 - CS24) which were explained in Table 3 as follows.

Table 3. Rotarian Component Matrix

\begin{tabular}{llllll}
\hline & 1 & 2 & 3 & 4 & 5 \\
\hline NH1 & 0.525 & & & & \\
NH2 & 0.646 & & & & \\
NH3 & 0.519 & & & & \\
NH4 & 0.617 & & & & \\
C5 & & 0.490 & & & \\
C6 & & 0.765 & & & \\
C7 & & 0.657 & & & \\
SR8 & & & 0.702 & & \\
SR9 & & & 0.698 & & \\
SR10 & & & 0.22 & \\
SR11 & & & 0.598 & & \\
SR12 & & & 0.572 & & \\
H18 & & & & 0.589 & \\
H19 & & & & 0.441 & \\
H20 & & & & 0.509 & \\
CS21 & & & & 0.615 & \\
CS22 & & & & 0.822 & \\
CS23 & & & & 0.791 & \\
CS24 & & & & 0.573 & \\
\hline
\end{tabular}

\section{RESULT AND DISCUSSIONS}

The results of this research revealed that the Cronbach's alpha coefficient value for natural harmony was 0.814 , the community was 0.857 , self renewal was 0.821 hedonism was 0.864 , and consumer satisfaction was 0.826 .
Consequently, it could be concluded that the answers of each respondent to the statements in this research variable were consistent, thus helping each item measured the concepts it measured. The test results of $\mathrm{R}$ square explained in the Table 4 as follow. 
Table 4. $R$ Square Test Result

\begin{tabular}{cccc}
\hline $\mathrm{R}$ & $\mathrm{R}_{2}$ & Adjusted $\mathrm{R}_{2}$ & $\mathrm{f}$ \\
\hline 0.739 & 0.576 & 0.569 & 88.496 \\
\hline
\end{tabular}

Based on the F statistic test, the results of the regression analysis showed that the coefficient value for determination (R2) was 0.576 while the remaining 0.424 was influenced by other unexamined factors. The results of the regression analysis were explained in the Table 5.

Table 5. Regression Analysis Results

\begin{tabular}{llll}
\hline Variable & Coefficient Standard & $\begin{array}{c}\text { T } \\
\text { Statistic }\end{array}$ & Sig \\
\hline NH & 0.228 & 3.754 & 0.000 \\
C & 0.132 & 2.631 & 0.001 \\
SR & 0.144 & 2.544 & 0.001 \\
H & 0.137 & 3.216 & 0.001 \\
\hline
\end{tabular}

Accordingly, overall, the relationship among variables in this research could be explained in Table 6 below.

Table 6. Test Result

\begin{tabular}{|c|c|c|}
\hline Correlation & Hypothesis Sign & Description of Test Results \\
\hline $\mathrm{NH} \rightarrow \mathrm{CS}$ & $\mathrm{H} 1(+)$ & $\begin{array}{l}\text { Positive, } \\
\text { Significant, the hypothesis is accepted }\end{array}$ \\
\hline $\mathrm{C} \rightarrow \mathrm{CS}$ & $\mathrm{H} 2(+)$ & $\begin{array}{l}\text { Positive, } \\
\text { Significant, the hypothesis is accepted }\end{array}$ \\
\hline $\mathrm{SR} \rightarrow \mathrm{CS}$ & $\mathrm{H} 3(+)$ & $\begin{array}{l}\text { Positive, } \\
\text { Significant, the hypothesis is accepted }\end{array}$ \\
\hline $\mathrm{H} \rightarrow \mathrm{CS}$ & $\mathrm{H} 4(+)$ & $\begin{array}{l}\text { Positive, } \\
\text { Significant, the hypothesis is accepted }\end{array}$ \\
\hline
\end{tabular}

The positive regression coefficient values were found in all relationship of influencing factors on consumer satisfaction, meaning that the results of this research supported Arnould and Price's (1993) research. In addition, the research development adding hedonic factors also had a positive and significant effect on customer satisfaction.

Furthermore, these results also supported the research from Hirschman and Holbrook (1982); Babin, Darden, and Griffin (1994) who stated that hedonism influenced consumer satisfaction because individuals preferred to choose symbolic products to functional products in order to obtain satisfaction.

The implications of this research results on theoretical studies were the research results and models had predictive accuracy and were scientifically accountable. As a result, it could be developed and tested with different approaches and paradigms in a broader context.

Meanwhile, the implications of the results of this research on practical studies were the adventure 
tourism product service providers could obtain empirical and contextual evidence, thus, the development of adventure product services could be further expanded.

\section{CONCLUSION}

The result of this research reveals that the natural harmony has the highest positive and significant influence among the other influencing factors on the satisfaction of rafting adventure tourism product consumers. The development of research model based on Arnould and Price's (1993) research model by using the hedonic variable shows a positive and significant influence on the satisfaction of rafting adventure tourism consumers. All indicators examined and constructed are

\section{REFERENCES}

Addis, $\mathrm{M}$ and Holbrook, M.B. (2001). On the conceptual link between mass customisation and experential consumption: An explosion of subjectivity. Journal of Consumer Behavior, Vol 1, 50-66.

Arnould, E.J. and Price, L.L. (1993). River Magic: Hedonic consumption and the extended service encounter. Journal of Consumer Research, Vol 20, 2445.

Babin, B. J., Darden, W.R., and Griffin, M. (1994). Work and fun: Measuring Hedonic and Utilitarian Shopping Value. Journal of Consumer Research, Vol 20, 644-656.

Bitner, M. J., Bernard, H.B and Mary, S.T. (1990). The service encounter; Diagnosing favorable perceived as good or strong by the respondents.

Moreover, this research opens a gap for future research to reveal other variables as an extension of the factors influencing satisfaction of adventure tourism products. This research is limited to certain adventure tourism communities and focuses on antecedents.

This research also has limitations on perspectives, theoretical foundations, time, and research objects. Research with a long time dimension is strongly recommended to provide a better evidence of causality among variables. In addition, it is expected that the further research can cover other adventure tourism communities.

and unfavorable incidents, Journal of Marketing, Vol. 54, 71-84.

Celsi,R, Randall, L.R, and Thomas, W.L. (1993). An exploration of high risk leisure consumption through skydiving. Journal of Consumer Research, Vol 20,123.

Csikszentmihalyi, M and Judith L., (1989). Optimal experience in work and leisure. Journal of Personality and Social Psychology, Vol 56, 599-611.

Havlena, W and Morris B H. (1986). The varieties of consumption experience: comparing two typologies of emotion in consumer behavior. Journal of Consumer Research, Vol 13, 394-404.

Hirschman, E.C. (1984). Experience seeking: a subjectivist 
perspective of consumption. Journal of Business Research, Vol 12, 115-136.

Hirschman, E. C. and Morris B. H., (1982). Hedonic consumption: emerging concepts, methods and propositions. Journal of Marketing, Vol 46, 92-101.

Holbrook, M. B. (1994). The nature of customer value: An axiology of services in the consumption experience. In R. T. Rust and R. L. Oliver (Eds.), Service Quality: New Directions in Theory and Practice.21-71. Thousand Oaks, CA: Sage.

Holbrook, M. B. (2001). Customer value - a framework for analysis and research. Advances in Consumer Research, Vol. 23, 138-142.

Morris, B.H., Robert, W C, Terrence, A O., and Eric, A G. (1984). Play as a consumption experience: the role of emotions, performance and personality in the enjoyment of games, Journal of Consumer Research, Vol 11, 728-739.

Morris B.H, and Hirchman. E. (1982). The experiential aspects of consumption: consumer fantasies, feelings, and fun. Journal of Consumer Research, Vol 9, 132-140.

Otto, J and Ritchie, J. (1995). Exploring the quality of the service experience: A theoretical and empirical analysis. Advances in services marketing and management: Research and Practice, Vol 4, 37-62.

Otto, J and Ritchie, J. (1996). The service experience in tourism. Tourism Management, Vol 17, 165-174

Oliver, R.L. (1980). A cognitive model of the antecedents and consequences of satisfaction decisions. Journal of Marketing Research, Vol17, 460-469.

Oliver, R. L and Wayne, S D. (1988). Response determinant in satisfaction judgment. Journal of Consumer Research, Vol 14, 495-507.

Price, L.L., Arnould, E.J., and P. Tierney, P. (1995). Going to extremes: managing service encounters and assessing provider performance. Journal of Marketing, Vol 59, 83-97. 